NOTE

\title{
First record of Cymothoa indica (Crustacea, Isopoda, Cymothoidae) infecting the cultured catfish Mystus gulio in India
}

\author{
M. Rajkumar' ${ }^{1}$, K. P. Kumaraguru vasagam ${ }^{1}$, P. Perumal' ${ }^{1}$, J. P. Trilles ${ }^{2, *}$ \\ ${ }^{1}$ Centre of Advanced Study in Marine Biology, Annamalai University, Parangipettai - 608 502, Tamil Nadu, India \\ ${ }^{2}$ UMR 5171 (UM2-IFREMER-CNRS) (Genome, Populations, Interactions, Adaptations), Equipe Adaptation Ecophysiologique \\ et Ontogenèse, Université de Montpellier 2. CC 092, Place Eugène Bataillon, 34095 Montpellier cedex 5, France
}

\begin{abstract}
Cymothoa indica (Isopoda, Cymothoidae) is reported parasitizing the long-whiskered catfish Mystus gulio, cultured in an experimental cage in India. The specimens observed were adult males and females, which had mainly settled in the buccal cavity of juvenile catfish. The species was previously known from wild populations of Siganidae and Belonidae, but this is the first record of $C$. indica parasitizing the cultured long-whiskered catfish. Serious lesions, typical of a crustacean infection, were macroscopically visible inside the buccal cavity. The cumulative mortality, over a period of $10 \mathrm{~d}$, was $100 \%$. The parasitic problem was not successfully dealt with, due to an unexpected prevalence and very swift mortality.
\end{abstract}

KEY WORDS: Cymothoidae $\cdot$ Isopoda $\cdot$ Parasite $\cdot$ Cymothoa indica $\cdot$ Mystus gulio $\cdot$ India

\section{INTRODUCTION}

Parasites play an important role in the biology of fishes and can affect their behaviour, health and distribution (Rohde 1993). Several facultative and/or obligatory Isopoda species are deleterious parasites of fishes, often with tremendous destructive activity (Trilles 1969, Maxwell 1982). They are a significant component of the parasitic fauna of fishes and are important economically and ecologically, but little is known about their biology (Williams \& Bunkley-Williams 1994). Aquaculture is the fastest growing agribusiness sector, which often faces great economic losses due to problems caused by disease. Such losses have resulted from sporadic parasitic invasions in cage culturing systems (Raibaut et al. 1980, Euzet et Raibaut 1985, Cabral \& Raibaut 1987, Cassier et al. 1998).

Isopods are an important group of crustacean parasites of fishes. To date, more than 450 species have been identified parasitizing freshwater and marine teleosts, as well as elasmobranchs (Kabata 1985, Moller \& Anders 1986, Trilles 1994, Trilles \& Öktener 2004). Most are cymothoids, flabelliferan isopods with a short free-living planktonic phase; adults are exclusively parasitic and the presence of a few individuals can cause damage to hosts. They are protandric hermaphrodites, living on the skin, in the gill chambers, or in the mouth of the fish. They feed on host blood, plasma in wounds and fish tissue, sometimes resulting in impressive tissue damage (Trilles 1969, Romestand 1979, Williams \& Bunkley-Williams 1994).

The parasitic effects include growth retardation, emaciation and frequently the death of the infected fish. Mortality is increased by weight loss resulting from the weakened condition of the parasitized fish. Hyper-infections by isopods can kill fish (Williams \& Bunkley-Williams 1994); fish in captivity are especially susceptible (Mugridge \& Stallybrass 1983). On coral 
reefs, cymothoid isopods affect the growth and fecundity of damselfish (Adlard \& Lester 1995) and other fish (Lester \& Roubal 1995). To date, several species of cymothoid isopods infecting cultured fish have been reported: Ceratothoa gaudichaudii (Milne Edwards, 1840) from salmon Salmo salar farmed in seawater in southern Chile (Roa 1992, Inostroza et al. 1993, Lobos 1994, Sievers et al. 1996); Nerocila orbignyi (GuerinMeneville, 1829-1832) parasitizing cage-cultured seabass Dicentrarchus labrax, transferred from wild mullet in Diana Pond in Corsica (Bragoni et al. 1983, 1984); Emetha audouini (Milne-Edwards, 1840) from cultured sea bass in Greece, transferred from wild populations of Sparidae or Centracanthidae (Papapanagiotou et al. 1999); Ceratothoa oestroides (Risso, 1826), from cultured sea bass and sea bream Sparus aurata in Croatia (Sarusic 1999); Ceratothoa parallela (Otto, 1828) from cultured gilthead sea bream Sparus aurata in Greece (Papapanagiotou \& Trilles 2001).

This is the first record of Cymothoa indica (Schiodte and Meinert, 1884) parasitizing the long-whiskered catfish Mystus gulio Hamilton and Buchanan, 1822 (Bagridae). The fish infected were specifically cultured in an experimental cage in India.

\section{OBSERVATIONS}

In September 2003, a severe outbreak of buccal parasitic infection occurred in an experimental cage culture of catfish in the Vellar estuary $\left(11^{\circ} 29^{\prime} \mathrm{N}\right.$, $79^{\circ} 49^{\prime}$ E) on the southeast coast of India, where commercial fish farming is still absent. The experimental culture started in June 2003 with an initial stocking of 20 juveniles $\mathrm{m}^{-2}$ of Mystus gulio (mean body length and weight of $5.5 \pm 1.25 \mathrm{~cm}$ and $3.7 \pm 1.05 \mathrm{~g}$, respectively). The juveniles were wild collected from the tidal pools in and around the Vellar estuary. The dimensions of the cage were $5 \times 6 \times 1.5 \mathrm{~m}$ and it consisted of highdensity polyethylene filaments. The stocked catfish were fed with formulated feed having a crude protein level of $37 \mathrm{~g} \mathrm{~kg}^{-1}$. The feed was offered in 2 rations per day (07:00 and 18:00 h). The salinity of the ambient water ranged between 28 and $31 \%$, water temperatures between 22 and $24.50^{\circ} \mathrm{C}$, and $\mathrm{pH}$ between 7.8 and 8.2 .

Three months after the initial stocking, unexpected mass mortality occurred and the entire population of fishes died within $10 \mathrm{~d}$. The occurrence peaked during the last $3 \mathrm{~d}$. The dead or dying specimens were collected. A total of 216 dead fish and 83 in the dying stages were carefully examined. All of these fish were found to be infected by cymothoids. The parasites observed in the buccal cavities were removed and identified as Cymothoa indica according to Trilles
(1975), Veerapan \& Ravichandran (2000) and Rajkumar et al. (2004). In all cases, the parasites had settled on the floor of the buccal cavity of the host and clung firmly to the tongue with their heads pointed in the anterior direction. The number of parasites on each fish ranged between 1 and 3 and were found to be alive as long as 5 to $6 \mathrm{~h}$ after the death of the host.

The host reactions to the irritation caused by the parasite included wide opening of the mouth and often biting on a hard substratum like the cage rope or net. The body surface of the dying fish was covered and the buccal cavity filled with excessive mucus. Reddening of muscles around the site of infection and intense darkening of the body were also observed. The clinical signs included loss of condition, anorexia and erratic swimming behavior.

No other parasitic organisms were observed that might be associated with such a disease.

\section{COMMENTS}

For the first time, Cymothoa indica is reported infecting cage-cultured catfish in India. Among the wildcollected population of Mystus gulio, no specimen was infected by this parasite. At the same time, other wild fishes like Nematolosa nasus and Siganus javus were found parasitized by C. indica (M. Rajkumar pers. obs.). Veerapan \& Ravichandran (2000) recorded a similar infection of the wild fishes Sphyraena obtusata and Trachinocephalus myops. Rajkumar et al. (2004) observed a severe parasitism by $C$. indica in the buccal cavity of the spot tail needlefish Strongylura strongylura.

The first report of cymothoid isopods in an aquaculture system was from seabass Dicentrarchus labrax reared in ponds (Bragoni et al. 1983, 1984). Subsequently, several species of cymothoid isopods were found to be infectious on several cultivable fishes, causing severe mortalities and consequent economic losses in commercial farming activities (see 'Introduction').

The high level of infection suggests that Mystus gulio might, under certain conditions, be an appropriate host for Cymothoa indica. Increased parasitic prevalence with the onset of the monsoon rains proves that the climatic conditions prevailing during this time are favourable for the reproduction of parasites (Leonardos \& Trilles 2003). The high temperatures of the ambient water during this season might be conductive to a prolonged presence and proliferation of C. indica (Trilles 1968, Papapanagiotou \& Trilles 2001). Settlement of the parasite in the tongue region of the buccal cavity, along with blood sucking, can result in reduced feed intake (anorexia) and disturbed 
respiration of the host. Excessive mucus secretion by the infected fish is a host response evoked to overcome the irritation caused by the parasite and has already been noted as an accompanying sign in all diseases induced by parasitic isopods (Trilles 1968, 1969, Romestand 1978, 1979, Bragoni et al. 1983, 1984). The nutritional quality of the formulated feed provided to the cultured fish was perhaps inadequate, and this, in turn, may have partly suppressed the immune system of the fish and supported the parasitic infection (Verlhac \& Gabaudan,1994, Verlhac et al. 1995).

The control of cymothoid proliferation in aquaculture is sometimes possible by implementing optimum husbandry management practices. Transmission of infection by cymothoid larvae can be prevented by using small-sized mesh nets around the cages (Bragoni et al. 1983, 1984). It is recommended that the moribund and dead fish be removed daily from the cages to avoid persistent infection, and the cages can be moved away from the site of infection into the open sea, where there are stronger currents, lower temperatures and greater depths (Papapanagiotou et al. 1999, Papapanagiotou \& Trilles 2001).

In this case of Cymothoa indica parasitizing Mystus gulio, the management failed to take any control measures, due to the unexpected and colossal outbreak of the parasitic infection and subsequent mass mortality which occurred within a short period of time. The data reported here make a very useful contribution to the development of aquaculture in general and particularly of catfish aquaculture in India.

Acknowledgements. We thank the reviewers, Dr. Kabata and anonymous reviewers, for their positive comments which substantially improved this article.

\section{LITERATURE CITED}

Adlard RD, Lester RJG (1995) Dynamics of the interaction between the parasitic isopod, Anilocra pomacentri and the coral reef fish, Chromis nitida. Parasitology 109:311-324

Bragoni G, Romestand B, Trilles JP (1983) Parasitoses à Cymothoadien chez le loup (Dicentrarchus labrax Linnaeus, 1758) en élevage. II. Ecophysiologie parasitaire dans le cas de l'étang de Diana (Haute-Corse). Ann Parasitol Hum Comp 58(6):593-609 (English Abstract)

Bragoni G, Romestand B, Trilles JP (1984) Parasitoses à Cymothoadien chez le loup Dicentrarchus labrax (Linnaeus, 1758) en élevage. I. Ecologie parasitaire dans le cas de l'étang de Diana (Haute-Corse) (Isopoda, Cymothoidae). Crustaceana 47(1):44-51 (English Abstract)

Cabral P, Raibaut A (1987) Découverte d'un Copépode Caligide nouveau parasite du tégument du loup Dicentrarchus labrax (L., 1758) (Pisces, Moronidae) en élevage et en milieu naturel. Bull Soc Zool Fr 111(1-2):123-130 (English Abstract)

Cassier P, Brugerolle G, Combes C, Grain J, Raibaut A (1998) Le parasitisme. Un équilibre dynamique. Masson, Paris

Euzet L, Raibaut A (1985) Les maladies parasitaires en pisci- culture marine. Symbioses 17:51-68 (English Abstract)

Inostroza R, Sievers G, Roa J, Aguirrebena R (1993) Prevalencia e intensidad de infeccion estacional por Ceratothoa gaudichaudii en salmones (Salmo salar) cultivados en aqua de mar en el sur de Chile. Arch Med Vet (Valdivia) XXV(2):173-179 (English Abstract)

Kabata Z (1985) Parasites and diseases of fish cultured in the tropics. Isopoda. Taylor \& Francis, London

Leonardos I, Trilles JP (2003) Host-parasite relationships: occurrence and effect of the parasitic isopod Mothocya epimerica on sand smelt Atherina boyeri in the Mesolongi and Etolikon Lagoons (W. Greece). Dis Aquat Org 54: 243-251

Lester RJG, Roubal FR (1995) Phylum Arthropoda. In: Woo PTK (ed) Fish diseases and disorders, Vol 1. Protozoan and Metazoan infections. CAB International, Wallingford, p 475-598

Lobos BCI (1994) Accion del isopodo Ceratothoa gaudichaudii sobre el peso corporal de salmones del atlantico (Salmo salar). Tesis de Grado de Licenciado en Medicina Veterinaria, Universidad Austral de Chile, Facultad de Ciencias Veterinarias, Valdivia

Maxwell JGH (1982) Infestation of jackmackerel Trachurus declivis (Jenyns), with cymothoid isopod, Ceratothoa imbricatus (Fabricius) in Southeastern Australian waters. J Fish Biol 29(3):341-349

Moller H, Anders K (1986) Diseases and parasites of marine fishes. Moller, Kiel

Mugridge RER, Stallybrass HG (1983) A mortality of eels, Anguilla anguilla L., attributed to Gnathiidae. J Fish Biol 6:81-82

Papapanagiotou EP, Trilles JP (2001) Cymothoid parasite Ceratothoa parallela inflicts great losses on cultured gilthead sea bream Sparus aurata in Greece. Dis Aquat Org 45: $237-239$

Papapanagiotou EP, Trilles JP, Photis G (1999) First record of Emetha audouini, a cymothod isopod parasite, from cultured sea bass Dicentrarchus labrax in Greece. Dis Aquat Org 38:235-237

Raibaut A, Divanach P, Coste F, Maillard C (1980) Copépodose larvaire en écloserie de poissons marins. La Piscicult Fr 61/62:49-51

Rajkumar M, Santhanam P, Perumal P (2004) Report on new host record of Cymothoa indica Schioede and Meinert, 1884 (Crustacea: Isopoda) from Parangipettai coastal waters, southeast coast of India. J Aquat Biol 19(2): 113-114

Roa RJE (1992) Contribution al estudio del isopodo Ceratothoa gaudichaudii como parasito de salmones (Salmo salar) cultivados en aqua de mar en dos centros de cultivo de la provincia de Llanquihue. Tesis de Grado de Licenciado en Medecina Veterinaria. Universidad austral de Chile, Facultad de Ciencias Veterinarias, Valdivia

Rohde K (1993) Ecology of marine parasites, 2nd edn. CAB International, Wallingford

Romestand B (1978) Etude écophysiologique des parasitoses à Cymothoidae. PhD thesis, University of Montpellier II, Montpellier (English Abstract)

Romestand B (1979) Etude écophysiologique des parasitoses a Cymothoadiens. Ann Parasitol Hum Comp 54(4):423-448

Sarusic G (1999) Preliminary report of infestation by isopod Ceratothoa oestroides (Risso, 1826), in marine cultured fish. Bull Eur Assoc Fish Pathol 19(3):110-112

Sievers G, Lobos C, Inostroza R, Ernst S (1996) The effect of the isopod parasite Ceratothoa gaudichaudii on the body weight of farmed Salmo salar in Southern Chile. Aquaculture 143:1-6 
Trilles JP (1968) Recherches sur les isopodes Cymothoidae des côtes francaises. PhD thesis, University of Montpellier II, Montpellier

Trilles JP (1969) Recherches sur les isopodes Cymothoidae des côtes francaises. Apercu général et comparatif sur la bionomie et la sexualité de ces Crustacés. Bull Soc Zool Fr 94(3):433-445 (English Abstract)

Trilles JP (1975) Les cymothoidae (Isopoda, Flabellifera) des collections du Muséum National d'Histoire Naturelle de Paris.III. Les Cymothoidae Schioedte et Meinert, 1884. Genre Cymothoa Fabricius, 1787. Bull Mus Natl Hist Nat Zool (255)318:977-993 (English Abstract)

Trilles JP (1994) Les Cymothoidae (Crustacea, Isopoda) du Monde (Prodrome pour une faune). Stud Mar 21/22(1-2) (1991):5-288

Trilles JP, Öktener A (2004) Livoneca sinuata (Crustacea; Isopoda; Cymothoidae) on Loligo vulgaris from Turkey, an

Editorial responsibility: Wolfgang Körting,

Hannover, Germany unusual cymothoid associations. Dis Aquat Org 61: $235-240$

Veerapan N, Ravichandran S (2000) Isopod parasites from marine fishes of Parangipettai coast. UGC-SAP Monograph series, Annamalai Univerisity, Parangipettai

Verlhac V, Gabaudan J (1994) Influence of vitamin C on the immune system of salmonids. Aquacult Fish Manag 25:21-36

Verlhac V, Gabaudan J, Schuep W (1995) Immunomodulation in fish: II. Effect of dietary vitamin C. In: Kurmaly K (ed) Proceedings of the 2nd Roche Aquaculture Centre Conference on Nutrition and Disease, June 15th, 1995, Bangkok, Thailand. Roch Aquaculture Centre AsiaPacific, Bangkok, p 53-58

Williams EH Jr, Bunkley-Williams L (1994) Four cases of unusual crustacean-fish associations and comments on parasitic processes. J Aquat Anim Health 6:202-208

Submitted: August 9, 2004; Accepted: February 14, 2005

Proofs received from author(s): July 2, 2005 